\title{
Współczesna literatura rosyjsko-izraelska na przykładzie powieści Dennisa Soboleva Legendy góry Karmel. Czternaście historii o miłości i czasie
}

\author{
Abstract \\ Contemporary Russian-Israeli Literature by the Example of Dennis Sobolev's Novel Legends \\ of Mount Carmel. Fourteen Stories about Love and Time
}

The great aliyah influenced the nature of Russian-language literature in Israel at the end of 1980 s and the beginning of 1990s. Not only did it increase the number of creators writing in Russian, but it also became a potential that changed the nature of the latest Russian-Israeli literature. The basis for its evolution is the process of deminorization (the concept of Roman Katsman). It reveals itself mainly (though not only) in the revision of the subjects that have been covered hitherto - literature expands the spectrum of the world view and aims towards universalism; it becomes ambiguous, filled with philosophical thought, metaphysics and mysticism. Evolution is revealed not only in the content-ideological layer, but also in the composition of works. The character of the latest Russian-Israeli literature perfectly reflects the work of Dennis Sobolev, especially his second novel, Legends of Mount Carmel. Fourteen Stories about Love and Time.

Keywords: Dennis Sobolev, Russian-language literature in Israel, deminorization

Słowa kluczowe: Dennis Sobolev, Literatura rosyjskojęzyczna w Izraelu, deminoryzacja

Z kolejnymi alijami ze Związku Sowieckiego przybywały do Izraela setki literatów - pisarzy, poetów i publicystów. Pierwszy ich znaczący napływ nastąpił na przełomie lat sześćdziesiątych i siedemdziesiątych XX wieku. W Izraelu kontynuowali oni działalność literacką głównie w kształcie sprzed alii, tj. prezentowali kolejną odsłonę dobrze sobie znanej literatury zaangażowanej, o charakterze minorowym - opozycyjnej, antysowieckiej, demaskującej antysemityzm. Wymieńmy tu choćby Dawida Markisza czy Eli Luksemburga. 
Po około dwudziestu latach rosyjskojęzyczną przestrzeń literacką w Izraelu rozszerzyła wielka alija przełomu lat osiemdziesiątych i dziewięćdziesiątych (zwłaszcza lata 1990-1991). Znacząco podniosła ona wskaźnik ilościowy twórców piszących po rosyjsku, ale jednocześnie zweryfikowała wskaźnik jakościowy literatury „rosyjskiego Izraela” - i rzecz nie w jej wartościowaniu, lecz w ewolucji. Środowisko literackie zostało zasilone przez nowe pokolenie, urodzone pod koniec lat pięćdziesiątych, w latach sześćdziesiątych, a nawet siedemdziesiątych, wolne - co nie jest tu bez znaczenia - od traumatycznych doświadczeń uczestników poprzedniej alii. I ono właśnie stworzyło potencjał, który zmienił charakter najnowszej rosyjsko-izraelskiej literatury.

Eksplozja „nowej powieści” przypada na pierwsze dziesięciolecie XXI wieku, za sprawą przede wszystkim: Aleksandra Goldsztejna, Nekoda Singera, Jelizawiety Michailczenko i Jurija Nesisa, Michaiła Judsona, Aleksandra Barasza oraz Denisa Soboleva. Roman Katsman - znaczący izraelski literaturoznawca - ważną determinantę przeobrażenia rosyjskojęzycznej literatury w Izraelu widzi w mającym miejsce w dwóch ostatnich dekadach procesie jej deminoryzacji. Ujawnia się ona głównie (chociaż nie tylko) w rewizji podejmowanej tematyki. Literatura wchodzi na wyższy poziom postrzegania rzeczywistości, rozszerza spektrum oglądu świata i ewoluuje w kierunku nasyconego myślą filozoficzną uniwersalizmu; staje się wieloznaczna i wypełniona intelektualną autorefleksją. Nasila się jednocześnie jej metafizyczny i szczególny kulturowo-ontologiczny realizm od jego krańca egzystencjalnego po mistyczny ${ }^{1}$. Twórcy starają się kształtować świadomość historyczną i narodowościową odbiorców, w jakimś sensie tworzyć żydowski etos. Postawa bohatera w o be c świata zostaje zastąpiona jego istnieniem w świecie i tworzy nowe czasowo-przestrzenne kontinuum. Katsman pisze o intensywnej intelektualnej i kulturowej asymilacji w izraelską rzeczywistość - pozbawionej przy tym śladów ideologii i polityki; raczej w jakimś sensie magicznej ${ }^{2}$.

Ewolucja rosyjskojęzycznej literatury w Izraelu ujawnia się nie tylko w warstwie treściowo-ideowej, lecz także w kompozycji utworów. Cechuje je fragmentaryczność, z jednej strony odzwierciedlająca charakter wspólnoty, w której powstaje (repatrianci pochodzą z różnych krańców Związku Sowieckiego), a z drugiej nawiązująca - jak się wydaje - do struktury i interpretacyjnej otwartości midraszy. Fragmenty (opowiadania, eseje, części, rozdziały, bajki etc.) łączą się w dyssypatywną strukturę, rozumianą jako porządkowanie na nowo historycznej i kulturowej rzeczywistości, będącej w stanie chaosu ${ }^{3}$. W rezultacie tworzą się nowe sensy i/lub przeformułowaniu ulegają dotychczasowe.

1 Zob. R. Katsman, Wstęp, tłum. A. Mrózek [w:] Z Rosji do Izraela. Opowiadania, Katowice 2018, s. 6-7.

2 Zob. R. Katsman, Demarginalization of Contemporary Russophone Literature in Israel, http:// www.academia.edu/35544512/Demarginalization_of_Contemporary_Russophone_Literature_in_Israel (dostęp: 12.11.2018).

3 Zob. R. Katsman, Иерусалим: диссипативный роман Дениса Соболева, http://magazines. russ.ru/nlo/2017/1/ierusalim-dissipativnyj-roman-denisa-soboleva.html (dostęp: 10.12.2018). 
Charakter najnowszej rosyjsko-izraelskiej literatury doskonale oddaje twórczość Dennisa Soboleva, zwłaszcza jego druga powieść Legendy góry Karmel.

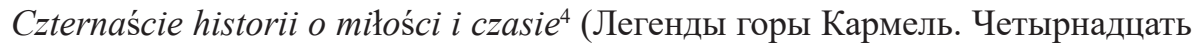
историй о любви и времени).

Sobolev, urodzony w Sankt Petersburgu (wówczas Leningradzie), miał 21 lat, kiedy w 1991 roku wyjechał do Izraela. Zamieszkał w Tel Awiwie, a po roku przeniósł się do Jerozolimy, gdzie na Uniwersytecie Hebrajskim studiował literaturę angielską i zdobywał kolejne stopnie naukowe. Jest niedoszłym fizykiem (trzy lata - jeszcze w Rosji - studiował fizykę), pisarzem, poetą, ale jednocześnie kulturologiem, filozofem, literaturoznawcą, profesorem Katedry Komparatystyki Uniwersytetu w Hajfie. Wiersze i prozę publikuje od roku 2000. Na jego dorobek składają się dziesiątki esejów i artykułów naukowych opublikowanych w wielu krajach, a także kilka książek literackich i naukowych. Powieść z 2005 roku pod tytułem Jerozolima (Иерусалим) w roku 2006 nominowano do Rosyjskiej Nagrody Bookera, natomiast wydane w 2016 roku w Petersburgu Legendy góry Karmel. Czternaście historii o miłości i czasie (Sobolev pisał je w latach 2009-2015) będące tu przedmiotem rozważań - uhonorowano nominacją do dwóch przyznawanych corocznie nagród: ,Narodowy bestseller” za najlepszą powieść rosyjskojęzyczną oraz nagrody imienia Arkadija i Borisa Strugackich za najlepszy utwór literatury fantastycznej. Twórczość literacką i eseistyczną Soboleva publikuje wiele czasopism, wśród nich rosyjskie „Вопросы литературы” oraz izraelskie: „22”, „Иерусалимский журнал” і „Артикль”.

Powieść Legendy góry Karmel. Czternaście historii o miłości i czasie wpisuje się swoją kompozycją w poetykę najnowszej literatury rosyjsko-izraelskiej. Prezentuje rodzaj kolażu, nacechowanego alegoryczną głębią, złożoną symboliką i polifonią fillozoficznej myśli. Stykamy się tu z poczwórną genologiczną kwalifikacją. Cechę gatunkową tytułowych 1 e gend stanowi, mówiąc w uproszczeniu, obudowanie faktów i/lub postaci historycznych oraz rzeczywistej topografii wymysłem, przy tym prawda historyczna i fikcja koegzystują w proporcjach określonych przez zamysł twórcy. Zawarte w podtytule słowo his torie sugeruje narrację opartą na fikcji, nazwanie zaś kolejnych rozdziałów utworu bajk a mi uzasadnia wprowadzenie do świata przedstawionego elementów fantastyki. Cechy genologiczne bajek i legend Sobolev traktuje selektywnie oraz instrumentalnie. Skupia się na ich głównym wyróżniku gatunkowym i traktuje go z jednej strony jako uzasadnienie kompozycyjno-semantycznej struktury utworu, a z drugiej - wyznacza mu rolę czynnika określającego strategię czytelniczego odbioru. Legendy... ponadto Sobolev nazywa powieścią, co a priori zakłada obecność nici spajającej wszystkie części utworu. Bajki są numerowane, ich kolejność jednak tylko częściowo wynika z rzeczywistej (historycznej) chronologii, nadrzędnym porządkującym faktorem pozostaje warstwa ideowa tekstu.

„Materialne” spoiwo powieści ma charakter geograficzny (przestrzenny), rolę tę odgrywa góra Karmel i rozłożone u jej podnóża miasto Hajfa. Karmel wią-

4 Tłumaczenia tytułów utworów Dennisa Soboleva, które pojawiają się w niniejszym szkicu autorka artykułu.

5 Zob. więcej: M. Michalska-Suchanek, Dennis Sobolev [w:] Z Rosji do Izraela ..., s. 106-109. 
że w Legendach... przeszłość z teraźniejszością, realność z fantastyką, narrację realistyczną - miejscami przypominającą naukowy, encyklopedyczny dyskurs z konwencją gawędy. Jawi się tu jako forma jedni, która kumuluje w sobie prawdę historyczną w jej dynamicznym rozwoju i literacką fikcję. Topograficzny locus określa wymowę semantyczną, ale również swoisty klimat Legend... Nazwa Karmel, po hebrajsku Har HaKarmel, znaczy „Boży ogród”, co można odczytywać jako usytuowanie góry w „sferze wpływu” tajemniczej Wyższej Siły (Boga?), decydującej o wydarzeniach i ludzkich losach. Narrator (trudno określić, czy w powieści narrator jest jeden, czy jest ich wielu, dla wymowy utworu nie ma to jednak żadnego znaczenia) rekapituluje: ,[...] Karmel była jedną z najstarszych gór, które przyciągnęły uwagę człowieka zarówno jako przestrzeń do życia, jak i miejsce, chroniące jakąś nieokreśloną — być może nawet w ogóle nie dającą się określić - tajemnicę" (s. 35) ${ }^{6}$. Stwierdzenie to wskazuje genezę ewokowanego przez świat przedstawiony nastroju niepokojącej zagadkowości i jednocześnie uzasadnia obecność fantastyki.

Strukturę powieści wyznacza konsekwentny podział każdej bajki na dwie części. Pierwsza część, ujęta w kluczu kronikalno-protokolarnym, określa historyczną czasoprzestrzeń opisywanych wydarzeń ze szczególną dbałością o uwiarygodniające uszczegółowienie. Sobolev umiejętnie wykorzystuje tu wiedzę z zakresu historii powszechnej i dziejów judaizmu. Przywołuje źródła żydowskie, judaistyczne, chrześcijańskie i muzułmańskie - o charakterze filozoficznym, religijnym, historycznym, etnograficznym, literackim etc. - od Księgi Rodzaju, notatek XII-wiecznego żydowskiego podróżnika Beniamina z Tudeli i XVI-wiecznego traktatu św. Jana od Krzyża Droga na góre Karmel przez wypowiedzi Marmeduke'a Pickthalla i wystąpienia Dawida Ben-Guriona po utwory noblisty z 1966 roku Samuela Agnona. Odwołuje się do Talmudu i źródeł postalmudycznych. Przywołuje postaci historyczne, między innymi: średniowiecznego rabina i jednocześnie andaluzyjsko-żydowskiego poetę Salomona ben Jehuda ben Gabirola (Awicebrona); Izaaka Lurię - rabina i kabalistę, działającego w XVI wieku w Safedzie w Palestynie, uznanego za ojca nowoczesnej kabały; Abbę Chusziego, burmistrza Hajfy w latach 1951-1969 (w powieści wymienione są jego osiągnięcia dla rozwoju $\mathrm{Hajfy}^{7}$ ). W narrację Sobolev wplata odniesienia do kluczowych momentów w dziejach narodu żydowskiego - od czasów Kalifatu Bagdadzkiego i krzyżowców poprzez pierwszą wojnę światową do rzeczywistości wieku XXI. W Legendach... pomieszcza informacje między innymi o wygnaniu z Półwyspu Iberyjskiego w roku 1492, edyktem królów katolickich Ferdynanda i Izabeli, około dwustu tysięcy Żydów; o czasach panowania tureckiego w Palestynie, o okresie mandatu brytyjskiego i o rozwoju ruchu syjonistycznego. Pojawiają się nawiązania do Shoah, powstania państwa Izrael, wojny sześciodniowej w 1967 roku, wreszcie do sytuacji rosyjskich Żydów przybyłych do Izraela w latach 1990-1991. Sobolev przytacza również fakty dotyczące samej Hajfy, by wymie-

6 Wszystkie cytaty z powieści Dennisa Soboleva pochodzą z: D. Sobolev, Легенды горы Кармель: Четырнадиать историй о любви и времени, Sankt Petersburg 2016. Strony podawane są w tekście, tłumaczenie na język polski - autorka artykułu.

7 Por. https://sztetl.org.pl/pl/biogramy/5844-hushi-abba (dostęp: 1.10.2018). 
nić: proces tworzenia na początku XX wieku Technionu - do dziś świetnie rozwijającej się technicznej uczelni, powołanej do życia przez działający w Niemczech żydowski fundusz Ezra; powstanie Żydów marokańskich w dzielnicy Hajfy Wad Salib w roku 1959 czy drugą wojnę libańską (1982-1985), kiedy w kierunku miasta leciały rakiety z zajętego przez Hezbollah terytorium południowego Libanu.

Zabieg datowania, który pisarz chętnie stosuje, sprzyja uwiarygodnieniu narracji. Większość wskazanych dat jest zgodna z faktami, jak rok 1265, w którym Hajfę opanowała armia egipskich mameluków, 1187 - gdy miasto zajął Saladyn, sułtan Egiptu, albo 1516 - rok wkroczenia armii tureckiego sułtana Selima I Groźnego. $Z$ datowania jednak Sobolev nie rezygnuje również w przypadku wydarzeń fikcyjnych, zacierając $\mathrm{w}$ ten sposób granicę między prawdą historyczną i fikcją; np. „16 czerwca 1234 roku” (s. 38) na drodze z Hajfy do Akki pojawia się Izaak, bohater bajki trzeciej, postać nieposiadająca protoplasty.

W pierwszej części bajek Soboleva fakty dziejowe, autentyczne zdarzenia, osoby, miejsca stanowią pierwiastek dominujący, chociaż - jak było powiedziane - granice między prawdą historyczną i autorską kreacją rozmywają się. Nierzadko Sobolev stosuje zabieg ,legenda w legendzie”, tj. sięga po autentyczne legendy, jak tę o Genizie, mieszczącej się w grotach góry Karmel, w której chroniono zniszczone, więc wycofane $\mathrm{z}$ obiegu święte księgi. Znane legendy pojawiają się w powieści obok przetworzonych lub w całości będących wymysłem pisarza. Podobnie Sobolev operuje motywem dokumentu. Obok odwołań do tych autentycznych pojawiają się dokumenty „,domniemane" (mowa o ,jakimś" dokumencie czy liście albo ,jednym z...”), relacje jakoby naocznych świadków, a także inne źródła, wystylizowane na prawdziwe.

Uprawdopodobnieniu narracji służy także nakładanie się powieściowej przestrzeni na rzeczywistą topografię Hajfy i jej okolic. Ten rodzaj etnografizmu stanowi wyróżnik rosyjsko-izraelskiej literatury; przypomnijmy choćby znaną powieść Diny Rubiny Oto idzie Mesjasz!, w której wydarzenia skrupulatnie odsłaniają topograficzną mapę Jerozolimy. ,[...] umie czytać miasto"8 - pisze Halina Waszkielewicz o Rubinie i słowa te można równie dobrze odnieść do twórczości Soboleva. Nie brakuje w jego powieści precyzyjnych, szczegółowych informacji, jakby zaczerpniętych z turystycznego przewodnika. Każda kolejna bajka przynosi materiał, który współtworzy holistyczny obraz Hajfy, zarówno współczesnej, jak i w jej historycznym rozwoju; obraz, który - w szerszym wymiarze interpretacyjnym - składa się na zarys dziejów narodu żydowskiego.

O ile w pierwszej części bajek przeważa, jak powiedziano, pierwiastek realny (realistyczny), o tyle część druga pozostaje pod znakiem fantastyki. Wypełnia ją surrealistyczna przestrzeń, w której rozgrywają się fantastyczne historie; w narracji pojawia się pierwiastek metafizyczny, a świat przedstawiony przybiera charakter symboliczny. „Innemu (drugiemu) światu” Sobolev - jak suponuje Natasza Rojtberg - wyznacza rolę ,zalustrza"9. To dobre określenie. Rozumieć

8 H. Waszkielewicz, Powietrzna trylogia Diny Rubiny [w:] Rosja w krysztale. Rozważania, fakty i miraże, red. D. Oboleńska, U. Patocka-Sigłowy, K. Arciszewska, K. Rutecka, Gdańsk 2014, s. 196.

9 N. Rojtberg, „Иерусалимский журнал” 2017, nr 56, http://magazines.russ.ru/ier/2017/56/o-novyh-knigah-vilyama-batkina-i-denisa-soboleva-pr.html (dostęp: 10.11.2018). 
je należy jako życie po drugiej stronie codzienności, rodzaj wizji (snu) o bycie alternatywnym, który przenika do naszego świata i powoduje, że człowiek odkrywa prawdziwego siebie. „Zalustrze” to klucz rozkodowujący realność (świat rzeczywisty), w rezultacie czego generuje się siła władna ją zmienić.

Na poziomie zewnętrznego uporządkowania Legend ... strategię odbioru - wyznaczoną przez interpretację metafizyczno-symboliczną - określają liczby siedem i czternaście, których symbolika jest dla judaizmu znacząca ${ }^{10}$. Na Legendy ... składa się czternaście rozdziałów-bajek (wcześniejsza powieść Soboleva, Jerozolima, liczy rozdziałów siedem). Liczbę siedem Sobolev eksponuje w bajce czternastej, zamykającej tom - O retrieverze $i$ burunduku (Про ретривера и бурундука), gdzie w biblijnej manierze stylistycznej narrator relacjonuje: „I była wielka bitwa czarnych psów i dresiarzy, trwała ona siedem dni i siedem nocy, i siedem razy psy atakowały, i siedem razy dresiarze ich zwyciężali” (s. 242).

Sijach, jedną z sześciu dolin otaczających Karmel, często - czytamy w Legendach... - mylnie thumaczy się jako „dolina słowa” lub nawet „dolina dyskursu” (s. 34). Bohaterem bajki O smoku z góry Karmel i hajfskiej genizie (O драконе горы Кармель и хайфской генизе) Sobolev czyni tytułową genizę zlokalizowaną w karmelskich grotach, co bez wątpienia należy postrzegać jako interpretacyjne wskazanie. „Słowu” pisarz nadaje w swojej powieści znaczenie kluczowe. Jak w starych chasydzkich przypowieściach staje się ono magią, cudem, dotyka ulotnej i niedefiniowalnej pierwobytnej istoty świata. Rywka, bohaterka bajki o genizie, wierzy, że słowa zawierają esencję wszelkich prawdziw ych wartości i uczuć, że: ,prawda mieści się tylko w słowie, gdyż tylko w słowie można zachować własną duszę" (s. 30); i „miłość może być tylko w słowie, i nie przechodząc przez słowo, nie może stać się miłością" (s. 30). Słowo oddaje (a przynajmniej sugeruje) immanentny sens zjawisk, rzeczy, zdarzeń, stanowi czystą jedyną prawdę $\mathrm{w}$ chaosie historii ${ }^{11}$.

Znaczenie ma przy tym każda litera składająca się na słowo. O tym, na ile ważna jest świadomość sensu wszystkich liter słowa, mówi narrator bajki $O p u$ stym doти w Halisie (Про пустой дом на Халисе). Jeśli się owego sensu nie rozpoznaje - twierdzi on - litera wcale nie przestaje „przemawiać”, tylko człowiek nie słyszy jej głosu, tkwiąc zamknięty we własnym egoistycznym ,ja”. To tak, jak w tekście Tory - każda litera niesie określoną treść, często ulotną i niedefiniowalną. Bezwzględnie ważny jest całościowy obraz wydarzeń, który odsłania sens stworzenia świata i powołania człowieka, ale jednocześnie kapitalnej ważności

10 Zgodnie z Księgą Rodzaju Bóg stworzył świat w ciągu sześciu dni, w dniu siódmym „,[...] ukończył Bóg [...] dzieło swoje, które uczynił, i odpoczął dnia siódmego od wszelkiego dzieła, które uczynił. I pobłogosławił Bóg dzień siódmy, i poświęcił go [...]” (Rdz 2,2-3). Siódmy dzień (szabat) wyraża pełnię doskonałości Bożego stworzenia. Bez tego dnia kreacja nie byłaby zakończona, gdyż zabrakłoby w niej wymiaru duchowego, uświęconego czasu „dla Boga”. Nowo stworzonemu światu Bóg nadał sześć kierunków: północ, południe, wschód, zachód, góra i dół. Siódmy punkt odniesienia stanowi miejsce, w którym usytuowany jest człowiek zajmujący, zgodnie z boską koncepcją, miejsce centralne. Zob. m.in. http://jekke.blox.p1/2016/12/Symbolika-liczb-w-judaizmie-1.html (dostęp: 10.11.2018).

11 Zob. A. Oz, F. Oz-Salzberger, Żydzi i stowa, thum. P. Paziński, Warszawa 2014. 
nabiera sam tekst postrzegany jako ciąg liter, które układając się w sekwencje znaków, kodują głęboką prawdę o świecie, w tym tę implikującą interpretacje mistyczne i magiczne ${ }^{12}$.

Mechanizm ten w jakimś sensie prezentuje bajka $O$ wielkim poecie Salomonie ibn Gabirolu i porcelanowej lalce (Про великого поэта Соломона ибн Габироля и фарфоровую куклу). Czasoprzestrzeń „fantastycznej psychologii” (s. 6), w której pogrąża się bohaterka, staje się w percepcji jej partnera (głównego bohatera historii) zlepkiem słów i terminów, związanych z psychodramą, neurolingwistycznym programowaniem, makrobiotykami, chińską medycyną, hinduską ajurwedą czy feng shui. „Stopniowo tych nowych słów stawało się już tyle, że Juwalowi zaczęło się wydawać, iż błądzi wśród nich, jak w ogromnym szarym lesie, wypełnionym jakimiś potwornymi mutantami fantazji” (s. 7-8). Metaforę tę można rozszerzyć na całą twórczość Soboleva - rozpoznawanie „lasu słów" i próbę odnalezienia się w jego gąszczu pisarz postrzega jako fundament ludzkiego istnienia. Zacytujmy Katsmana: „Narrator Sobolewa [...] owładnięty jest «pragnieniem rozumienia»; jego wzrok wbity jest w głąb fantastycznego «lasu», w którym rosną i przeobrażają się różne języki, symbole, teksty i kultury realne i zmyślone. W każdej minucie musi się starać na nowo rozumieć ten «las» i «uczyć się po nim chodzić»"13.

Nazwa Karmel tłumaczona jest - o czym była mowa - jako „Boży ogród”. Nasuwa to skojarzenie z tradycją znaną pod nazwą pardes (ogród, raj). PRDS to początkowe litery czterech równorzędnych poziomów interpretacji Pisma Świętego. Pierwszy - peszat (prostota) - zakłada dosłowne odczytanie sensu słów; drugi - remes (wskazówka) - odsłania znaczenia alegoryczne; trzeci - drasz (poszukiwanie, badanie) - ma charakter homiletyczny; ostatni zaś - sod (tajemnica) - konotuje treści mistyczne, ezoteryczne ${ }^{14}$. Podobną strategię interpretacyjną reprezentuje alegoreza (grec. allos - inaczej, agoreuo - mówić), którą pojmuje się jako dwupłaszczyznowy sposób odczytywania słów, wypowiedzi i znaków ikonicznych, polegający na jednoczesnym rozpoznawaniu ich znaczeń dosłownych oraz utajonych, będących istotą przekazu ${ }^{15}$.

Tego rodzaju strategia interpretacyjna doskonale wpisuje się w lekturę powieści Soboleva. Zakłada ona proces odbioru, w którego rezultacie odsłaniają się kolejne warstwy sensów i prowadzą odbiorcę ku światu ,po drugiej stronie bytu”. Bytu, który sytuuje się poza realną rzeczywistością, czyli tak naprawdę go nie ma, ale bez którego pełnia realn e g o życia przestaje być możliwa: ,[...] aby istnieć, nie mamy innego sposobu, niż uczynić to za pomocą tego, co nie istnieje" (s. 112). Alternatywny tajemniczy świat o k reśla ludzi, wyjawia, kim są, kim mogliby być i kim jeszcze stać się mogą.

12 Zob. S. Krajewski, Żydowskie studiowanie Tory, „Verbum Vitae” 2005, nr 7, s. 83-90, http:// dlibra.kul.pl/Content/21416/04_Krajewski.pdf(dostęp: 1.10.2018).

13 R. Katsman, Учиться ходить, „Нева” 2017, nr 5, http://magazines.russ.ru/media/uploads/2017/06/21/13_КАЦМАН.pdf (dostęp: 1.10.2018).

14 Zob. S. Krajewski, op. cit.

15 Zob. więcej A. Oz, F. Oz-Salzberger, op. cit. 
W tradycji żydowskiej istnieje przekonanie, że opowiadanie historii (dowolnej historii) jest czynnością magiczną, ujawnia prawdę o człowieku i świecie, a energia idei w niej zawartej wykracza poza ramy przedstawionej rzeczywistości. Słowo dawar - jawiło się w świadomości Izraelitów jako pojęcie oznaczające zarówno nieustanny ruch do przodu, jak i czyn. Jest ono „dynamiczną Wszechmocą Pana, żywiołową erupcją Jego Mocy"16 - pisze Roman Brandstaetter, oddając znaczenie dawar w języku polskim za pomocą neologizmu Słowoczyn ${ }^{17}$. Sobolev wyraźnie podąża tym tropem, gdy przekonuje, że każde słowo zamienia się w generator czynu i zyskuje moc sprawczą przeobrażania człowieka oraz przestrzeni wokół niego. Nie tylko kreuje rzeczywistość opowiadanej historii, lecz jednocześnie dokonuje przeobrażenia „prawdziwego” świata. Takie też jest w przekonaniu pisarza rudymentarne powołanie literatury.

W twórczości Soboleva w magiczność słowa wpisana jest jeszcze jedna wartość - uzewnętrznia ono żmudny proces wrastania w izraelską ziemię. „Wszystkie narody są spajane określoną narracją. Również żydowska tożsamość opiera się na powtarzanych przez pokolenia opowieściach. Dzięki nim Żydzi czują więź z poprzednimi pokoleniami i mają gwarancję, że następne generacje będą kultywować tradycje i zwyczaje"18 - powiada Szewach Weiss. U Soboleva obserwujemy to, co stanowi ważny wyróżnik rosyjsko-izraelskiego artystycznego i kulturowego realizmu - adaptowanie się w określonym środowisku kulturowym poprzez własne i subiektywne „materializowanie” za pomocą słowa żydowskiej tradycji, książkowych obrazów, ale także wiedzy i idei. Przywołajmy raz jeszcze myśl Katsmana, którą streścić można następująco: w nurcie realizmu epoki internetu, gdzie możliwe jest wszystko, co sobie wyobrażamy, a wszystko, co sobie wyobrażamy, okazuje się realne, napisane są historie z Hajfy, a słowa starych legend stają się w nich bardziej realne niż otaczająca rzeczywistość ${ }^{19}$. Sobolev personalizuje w ten sposób z jednej strony świadomość historyczną Izraela i narodu żydowskiego, a z drugiej - jego teraźniejszość.

Bajki Soboleva wydają się reakcją na ekspansywnie rozwijający się we współczesnym świecie posthistoryczny nihilizm i relatywizm. Kreowany przez pisarza „,inny świat” jawi się jako alternatywa dla rutynowości, merkantylności, egoizmu, introwersji i neurotyczności życia, w którym fundamentalne wartości oraz sens istnienia rozmywają się $\mathrm{w}$ - aby użyć dosadnego sformułowania Marka Amusina - „kwasowym środowisku psychoanalitycznych klisz pseudoduchowej gadaniny" ${ }^{20}$. Od aksjologicznej translokacji, wewnętrznej pustki, aberracji codzienności i historii oraz od iluzoryczności istnienia możliwy jest cud ucieczki w nowe życie. ,[...] z więzienia, które zwie się życiem, jest wyjście, i to wyjście

16 R. Brandstaetter, Czytanie Pisma Świętego jako modlitwa, Warszawa 1986, s. 74.

17 Ibid.

18 Sz. Weiss, Hagada, opowieść o tożsamości, https://wszystkoconajwazniejsze.pl/prof-szewach-weiss-hagada-opowiesc-o-tozsamosci/ (dostęp: 1.10.2018).

19 Zob. R. Katsman, Wstęp...

20 M. Amusin, Гора и город сквозь призму мифа, tłum. - autorka artykułu, Portal Intelros. Intellektualnaya Rossia, http://www.intelros.ru/readroom/druzhba-narodov/d4-2017/32797-gora-i-gorod-skvoz-prizmu-mifa.html (dostęp: 1.10.2018). 
nie jest śmiercią, lecz drogą" (s. 33) - pisze Sobolev w pierwszej bajce, a myśl ta wyznacza strategię odbioru całej powieści. Drogę, o której mowa w zacytowanym zdaniu, pisarz utożsamia z metamorfozą człowieka - odmieniona jednostka uczy się życia na nowo, zupełnie tak, jak w przywołanej wcześniej bajce $O$ wielkim poecie Salomonie ibn Gabirolu i porcelanowej lalce uczy się chodzenia tytułowa, cudownie ożywiona lalka.

Sobolev często eksponuje moment (,mechanizm”) przechodzenia bohaterów do ,innego świata". W bajce O pustym domu w Halisie funkcję bramy do alternatywnej rzeczywistości pełni stara szafa, stojąca w opuszczonym domu gdzieś w hajfskiej Halisie. Za jej drzwiami otwiera się świat, w którym wszystko jawi się jako lepsze i piękniejsze - czuje się dotyk wiatru, słyszy się szelest drzew, trawa jest bardziej zielona, a niebo wyższe. Bohaterowi historii, współczesnemu Izraelczykowi, programiście o imieniu Aleks, magiczna przestrzeń - ze stojącym w jej centrum zamkiem mieniącym się barwami oraz unoszącym się ponad jego murami smokiem - wydaje się,,bardziej wyrazista i prawdziwa niż jakiekolwiek wyjazdy zagraniczne, bez względu na to [...] jak wielkich pieniędzy by nie kosztowały” (s. 204). W „,innym świecie” respektowane są wartości, a ludzie bez trudu odróżniają dobro od zła: „W kraju, w którym się znalazł, były wysokie ośnieżone góry i cudowne istoty, umierające w imię danego słowa, a także mroczni ludzie, żyjący zgodnie z niezrozumiałą zasadą dzielenia wszystkiego na dobro i zło" (s. 205).

Fantastycznej wizji Sobolev przeciwstawia świat rzeczywisty - skomercjalizowaną codzienność, której istotę oddaje ironiczne, trywialne rozumowanie: „[...] dużo pieniędzy - to dobrze, a mało pieniędzy - źle. [...] Ponieważ świat leży na barkach tych, którzy mają dużo pieniędzy. [...] A dużo pieniędzy mają ci, którzy potrafią je liczyć. Dlatego świat leży na barkach tych, którzy potrafią liczyć pieniądze" (s. 196-197).

Wyraźnie zaznaczony jest kontrast między pełnią (prawdziwością) życia „,po tamtej stronie" a martwą egzystencją bohatera w świecie realnym. Wróciwszy do rzeczywistości, bohater pogrąża się w pustce, nieustannie prześladuje go wizja „innego świata”, czuje tęsknotę, ból, nieodparte pragnienie, aby tam powrócić. Rodzaj ideowej rekapitulacji stanowi finalna rozmowa Aleksa z duchem architekta-filozofa (notabene głównej postaci innej bajki). Zjawa snuje alegoryczną opowieść o roli pojedynczej litery we właściwym zrozumieniu sensu całego słowa (była o tym mowa wyżej). Należy - głosi - wsłuchiwać się w immanentne brzmienie liter, docierać do ich pierwobytnej istoty, a potem wszystko składać w treści, których sens odbiega - jak to zwykle się okazuje - od zwyczajowej, powierzchownej percepcji świata. Bajka O pustym domu $w$ Halisie kończy się duchowym przeobrażeniem (odrodzeniem) bohatera. Aleks uczy się po nowemu poznawać (doznawać?) rzeczywistość, wsłuchuje się w nią i odkrywa na nowo. W rezultacie granice między światem ,własnym” i ,innym” stopniowo zaczynają się zacierać. Nie bez znaczenia jest umiejscowienie wydarzeń w święto Purim, które upamiętnia wyzwolenie Żydów z rąk Hamana, dążącego do zgładzenia ich w całej Persji. W radosnym dla Żydów, świątecznym dniu bohater otrzymuje szansę na odmianę losu, swoje własne ,wyzwolenie”. 
Metamorfozę człowieka, przeistaczanie się w ,innego” Sobolev uczynił osią semantyczną także w bajce pod tytułem Dziewczynka i statek. Jest to historia spotkania dwóch pokoleń rosyjskich Izraelczyków. Nastolatka Lena - wyobcowana w rodzinie i w grupie, do której należy, zagubiona w świecie - boleśnie odczuwa samotność i odrzucenie, duchową i kulturową pustkę oraz chaos teraźniejszości. Przypadkowo poznaje należącego do pokolenia jej rodziców uczonego-matematyka, pracownika Technionu (Technion jest jednym z motywów łączących bajki w powieściową całość), który odkrywa przed nią świat legend, bajek i historii z przeszłości (jest to kolejny element spajający bajki w powieść - bohater nawiązuje bowiem do bajek, legend i historii, które pojawiły się we wcześniejszych częściach Legend...). Lena zapada w sen, a po chwili czuje, jak mieszkanie matematyka-bajarza zamienia się w statek i płynie wraz z nią do praźródeł, do metaforycznej ojczyzny - świata historii i książek, do pełni życia. Do świata, o którym marzyła Rywka (bohaterka bajki o genizie), pragnąca ujrzeć fantastyczne smoki, jednookich ludzi, dalekie kraje, tj. wszystko, o czym czytała w książkach. Statek przenosi Lenę w świat prawdy, skąd powróci już nie taka sama. Realność zlewa się z wizją oniryczną, gdyż jak pisze Sobolev w bajce $O$ pustym domu w Halisie: „[...] w snach właśnie ukryta jest realność” (s. 211).

Motyw przeobrażenia pojawia się też w bajce $O$ Beniaminie z Tudeli $i$ najściu babuinów (Про Беньямина из Туделы и нашествие бабуинов), która jednocześnie stanowi interesujący eksperyment formalny, rozwijający się w obraz społecznej satyry i antyutopii ${ }^{21}$. Pierwsza część utworu przybiera formę wykładu o zwyczajach babuinów, który oparty jest (jakoby) na autentycznych relacjach podróżników, w tym tytułowego Beniamina z Tudeli (XII-wiecznego żydowskiego podróżnika). Sobolev, wykorzystując dyskurs zawierający cechy opisu naukowego, stylizuje tę część bajki na pracę etnograficzno-przyrodniczą. Narrator eksponuje zadziwiającą racjonalność babuinów, ich złożony język symboliczny, wielopoziomową, świetnie zorganizowaną strukturę społeczną z dobrze określonymi rygorami i sposobami ich egzekucji. Ze szczegółowej, podpartej egzemplifikacją charakterystyki wyłaniają się cechy, postawy i zachowania małp, jak: chytrość, egoizm, egocentryzm, odrzucanie osobników, które nie są w stanie sprostać rygorystycznym normom obowiązującym w stadzie (np. potępianie samic, które nie doczekały się potomstwa), nienawiść, okrucieństwo obrzędów tzw. resocjalizacji, wreszcie samokaźń. Opis babuinów staje się w wizji Soboleva wielką alegorią, odsłaniającą złożoność międzyludzkich relacji.

$\mathrm{Na}$ drugą część bajki składa się narracja o dziewczynce, która jako jedyna z wioski przeżyła epidemię dżumy. Opustoszałą wieś opanowały babuiny, dziewczynka zaś za wszelką cenę pragnęła stać się jedną z nich. Dyskurs „,naukowy” zamienia się w przypowieść o samotności człowieka, który w zamian za przyjęcie do grupy, za akceptację decyduje się wyrzec tego, co najcenniejsze - własnego człowieczeństwa. Zasadność i wartość metamorfoz wyznaczona jest u Soboleva przez ich kierunek - bezwzględnie od negatywu do pozytywu. W przypadku prze-

21 Zob. A. Ророша, Легенды горы Кармель, http://www.sunround.com/club/journals/35popova. htm (dostęp: 10.10.2018). 
obrażenia (czy jego próby) z wektorem przeciwnym okazuje się ono niemożliwe. Człowieczeństwo jest najwyższą, niezniszczalną wartością; dziewczynka nie jest więc w stanie przejść procesu „babuanizacji”, tj. nauczyć się nie być człowiekiem.

Metamorfozie ze znakiem minus poświęcona jest również bajka pod tytułem $O$ kochajacym $i$ kochanym (О любящем и любимом). $\mathrm{Z}$ jednej strony jest to wystylizowana na opowieść z Baśni tysiąca i jednej nocy (której wydarzenia jakoby rozgrywają się w Hajfie) - historia tragicznej, nieodwzajemnionej miłości, w imię której ponosi się ofiary, a w zamian otrzymuje się jedynie cierpienie i samotność. Z drugiej zaś bajka opowiada o „testowaniu” miłości, określaniu cienkiej granicy, za którą dochodzi do psychologicznej transgresji - wielka miłość przeradza się w jeszcze większą nienawiść, a ofiara w kata.

Kluczowe znaczenie Sobolev przypisuje w Legendach... motywowi wieczności, ukazując bogate spektrum jej odsłon i odcieni. W bajce $O$ piratach Zatoki Hajfy (О пиратах Хайфского залива) na przykład przedstawia losy niejakiego Jakowa de Kuriela, niegdyś oficera kastylijskiej floty królewskiej, później przywódcy żydowskich piratów. De Kuriel wraz z towarzyszami napadał na hiszpańskie statki, mszcząc się w ten sposób na Hiszpanii i Kościele katolickim za wygnanie własnego narodu, a wszystko, co zagrabił, oddawał Żydom wygnańcom. Po jakimś czasie świadomość ofiar, które miał na sumieniu, zaczęła mu ciążyć, porzucił więc piractwo i oddał się kabale. Opowieść o zdradzie, zemście i przemianie bohatera wieńczy obraz de Kuriela, który ze szczytu góry Karmel, zwrócony twarzą ku morzu, godzinami wpatruje się w pustkę. I trwać tak będzie, jako duch, przez całą wieczność.

W jakimś sensie rezonuje tu myśl Franza Rosenzweiga o ciągłości (wieczności) istnienia narodu żydowskiego. Filozof zwraca uwagę na duchową istotę ludu Izraela, bardzo szczególną, odróżniającą go od narodów świata, która ukonstytuowała się, podobnie - co podkreśla - jak wszelkie źródła prawdy, poza nurtem historii (Rosenzweig podąża tu za koncepcją Samsona R. Hirscha, mimo że nie podziela jego ortodoksyjnych przekonań ${ }^{22}$. Nacechowane aktywnością duchową czasy talmudyczne uwolniły Żydów od podporządkowania się czasowi oraz miejscu i usytuowały ich w sferze wieczności. Żydowska „wieczność” „,...] bytuje poza historią «światową», wszedłszy w sferę «duchową»" "23, jest bezczasowa i nieskończona, jak wieczne są pustka i bezkres morza, w które już zawsze wpatrywać się będzie duch Jakowa de Kuriela.

Dotknąć wieczności, uchwycić jej istotę, usłyszeć język (,język wieczności”), w jakiś sposób ją zmaterializować - stało się nadrzędnym pragnieniem wielu postaci stworzonych przez Soboleva. Bohater bajki $O$ duchach zamku Rushmia (О духах замка Рушмия), malarz Izaak, wieczność łączy z pierwobytną istotą świata, jego immanentną prawdą i fundamentem - myślami zwierząt, drżeniem traw, odgłosami ptaków, mową barw, szumem wiatru, różnorodnością wcieleń ducha i pełnią ludzkich uczuć. Próbuje ten ,język" usłyszeć, zgłębić i wiernie od-

22 Zob. D.H. Frank, O. Leaman, Historia filozofii żydowskiej, przeł. P. Sajdek, Kraków 2009, s. 797.

23 Ibid., s. 797. 
dać w swoich pracach. Niestety to, co miało wyrażać esencję bytu, za każdym razem okazywało się, co prawda doskonałym, ale ty $1 \mathrm{k}$ o malowidłem. Zrozpaczony bohater zwraca się ku magii i wreszcie, w blasku porażającego światła, jego serce wypełnia upragnione uczucie. Wieczność objawia mu się jednak nie jako szum wiatru, morza i traw, Izaak czuje cały ,ból tego świata”, cierpienie ludzkości i ludzkie okrucieństwo. Jego serce nie wytrzymało tej erupcji energii i rozpadło się, przybierając formę magicznych węgielków, które zrodzone ze współczucia i empatii, wchłonęły „ogień” serca bohatera. Rozdawane przez Izaaka potrzebującym, przynosiły nadzieję, uzdrawiały dusze i ciała. Węgielki niestety zaczęto wkrótce wykorzystywać do ,niecnych” celów, gdyż - jak czytamy w innej bajce,,$-[.$.$] ludzie to istoty złe i nierozumne, niszczą siebie i świat wokół nich”$ (s. 242). Bohater pragnął poznać ,język wieczności”, lecz zamiast odkryć istotę bytu, ujawnił tylko odwieczną istotę człowieka; oddał światu wszystko, jemu zaś na wieki pozostało rozczarowanie, ,cisza i pustka” - jego własna wieczność (s. 50).

Zindywidualizowanie wieczności, ukazywanie jej z subiektywnej perspektywy bohatera - to charakterystyczne cechy powieści Soboleva. Sięgnijmy po jeszcze jeden przykład. Tematem bajki O opuszczonej synagodze $i$ jej duchach ( $О$ заброшенной синагоге и её духах) pisarz czyni samotność starca, mieszkającego wraz ze swoim psem w opuszczonej synagodze, na styku świata żywych i umarłych. Duchy synagogi stają się konkretyzacją własnej pamięci bohatera i pamięci cudzej, są jej - jak czytamy - „żywym biciem” (s. 171). Zwizualizowane wspomnienia wydarzeń i ludzi jawią się jako namacalne ślady wieczności - przebytego cierpienia, bólu, goryczy niespełnienia. Umierającemu starcowi ukazuje się spersonifikowana wieczność (jego własna, subiektywna). Jej „strażnik", Aron ha-kodesz, miejsce uświęcone przez przechowywane w nim zwoje Tory, personifikuje się i przybiera rysy ludzkiej twarzy (twarzy Boga?), z której bohater próbuje odczytać sens wieczności: „«Współczucie» - pomyślał starzec i zobaczył współczucie. «Nie» - powiedział do siebie - «surowy i sprawiedliwy sąd». I dokładnie tak samo ujrzał sprawiedliwy sąd, przed którym z pewnością był winien" (s. 175). Odpowiedzią na wątpliwości starca staje się - jak widać projekcja jego własnych myśli i lęków. Zgodnie z kabałą luriańską (Izaak Luria pojawia się w jednej z bajek) wyobrażenie Boga cechuje ambiwalencja - bywa miłosierny, ale także surowy ${ }^{24}$ - bohaterowi dane jest ujrzeć obydwa oblicza.

Jedno w opowiadanej historii jest pewne: wieczność nie jest równoznaczna ze śmiercią, lecz stanowi rodzaj transformacji jednego bytu w inny - nieskończony. Starzec nie godzi się na istnienie w jakiejkolwiek formie bytu bez ukochanego psa, zwierzę jest bowiem nierozerwalną częścią jego pamięci. W ostatnim wypowiedzianym życzeniu oddaje psu to, co najcenniejsze - wieczność wła sną w zamian za je g o wieczność: ,Życie - rzekł starzec - dla niego na zawsze, na całą [...] wieczność" (s. 177). Dalej następuje wzruszająca narracja o miłości psa, który nie chciał przejść do wieczności bez swojego pana.

24 Zob. L. Fijalkova, Между Хайфой, Хефой, Нефасой и Хефбургом: творимая легенда Дениса Соболева, „Новое литературное обозрение” 2017, nr 147(5), http://www.nlobooks.ru/ node/9033 (dostęp: 1.12.2018). 
Inną odsłonę subiektywnej wieczności bohatera Sobolev prezentuje w przywoływanej tu kilkakrotnie bajce $O$ wielkim poecie Salomonie ibn Gabirolu i porcelanowej lalce. Życie Juwala, bohatera opowieści, legło w gruzach na froncie drugiej wojny libańskiej. Traumatyczne przeżycia skutecznie odgrodziły go od normalności, zamknął się więc w swoim świecie, we własnej czasoprzestrzeni. Świat iluzji, jako jedyne constans w otaczającym go chaosie, stał się je go w i e c z n o ś c i ą, zapewniającą poczucie stabilności i bezpieczeństwa.

Zawarte w Legendach... myśli i idee cechuje hermeneutyczna otwartość. Sobolev nie wprowadza kategorycznych sądów, autorytarnie nie stawia kropek nad „i”. Przeciwnie - podkreśla niejednoznaczność aksjologicznej percepcji świata i relatywność pojęć. Reprezentatywny przykład stanowi bajka pod tytułem O szejku, architekcie i dwóch basztach (Про шейха, архитектора и две башни).

Tytułowy architekt o nazwisku Harrington projektuje dwie baszty: czarną i białą, które postrzega jako symbole dobra i zła. Sytuuje je w planie miasta tak, żeby każda z dróg bezpośrednio prowadziła do jednej z nich. Ma to w jego wizji przypominać mieszkańcom, że życie ludzi jest wyłączną konsekwencją dokonywanych przez nich wyborów. Wkrótce jednak okazuje się, że idealny, wydawałoby się, zamysł nie uwzględnia prostego faktu, iż świadomość dobra i zła - uzewnętrzniana przez wybór między nimi - stanowi rodzaj pozarozumowej i niedefiniowalnej tajemnicy, której odkrycie nie każdemu jest dane. Ponadto projekt czarno-białego świata pomija relatywność pojęć/jakości/wartości określających ludzki byt. W bajce odnajdujemy takie oto rozważania rozczarowanego bohatera: „Nadzieja to dobrze - mówił sobie, ale pusta i egoistyczna nadzieja to źle. Obowiązek, służba sprawie to dobrze, ale czyż dobra jest taka służba, która czyni nas niewolnikami rzeczy pustych i niskich? [...] przecież miłość [...] tak często prowadzi do unicestwienia i moralnego upadku, tak często wyrasta z obojętności wobec dobra i zła, tak często rodzi ślepe pożądanie lub pragnienie zemsty. Czyż można to wybrać?" (s. 117-118).

Prześladująca Harringtona wizja niekończących się wyborów, przybierających formę „pytań przeklętych”, wkrótce przeradza się w obsesję (bezwolnie nasuwają się skojarzenia z bohaterami Fiodora Dostojewskiego). Bohater zamyka się w świecie własnych halucynacji (wyraźne podobieństwo do postawy wobec życia Juwala - postaci z bajki O wielkim poecie Salomonie ibn Gabirolu i porcelanowej lalce), w którym prowadzi długie dysputy z urojoną nieznajomą. Mocnym podkreśleniem względności świata i relatywności fundamentalnych pojęć i wartości, zwłaszcza dobra i zła, Sobolev czyni zakończenie historii. Harrington uświadamia sobie, że od pewnego czasu wciąż na nowo przeżywa ten sam dzień, a wszystko wokół niego odbywa się według identycznego, wielokrotnie odgrywanego scenariusza. Zaczyna żyć w przekonaniu, że utknął we własnej odsłonie wieczności, a rzeczywistość, którą widzi i której doświadcza, jest zwykłym przywidzeniem. Ale i to w opowieści Soboleva okazuje się względne, finalna scena odwraca bowiem porządek - nie świat wokół Harringtona jest złudzeniem, lecz on sam okazuje się zjawą. 
O czym traktują Legendy... Soboleva? Przede wszystkim o odnalezieniu s i e b i e w skomercjalizowanej, współczesnej rzeczywistości i chaosie historii; o poznaniu prawdy o sobie i otaczającym świecie, o dotknięciu ulotnej pierwobytnej jego istoty, rozpoznaniu immanentnego sensu zjawisk, rzeczy, zdarzeń; o dotarciu do esencji wszelkich prawdziwych wartości i uczuć; wreszcie o upływie czasu, wieczności, lękach, pragnieniach i nadziei. Bohaterowie Soboleva w świecie zmieniających się wartości wytrwale poszukują punktów stałych. Wiedzę o nich osiągają, balansując na granicy przestrzeni fantastycznej i bytu realnego, w miejscu, gdzie dopiero co uświadomiona sobie prawda o nich samych generuje nowe oczekiwania wobec świata i własnego życia.

Rozwiązanie egzystencjalnego konfliktu między pragnieniem spełnienia się pożądanej wizji i realnością Sobolev widzi w metamorfozie człowieka. Proces przemiany doświadcza bohaterów - odradza, czasem też gubi. Ważny jest przy tym moment inicjacji - nowego zakorzenienia się w rzeczywistości, rodzaj powtórnej asymilacji, który zapoczątkowuje długi i mozolny proces nauki nowego życia. Nic nie jest z góry dane, wszystko trzeba zbudować na nowo - wolność, wieczność, a nade wszystko samego siebie. Z niejednolitością ludzkiego bytu i niejednorodnością przywoływanych historycznych faktów, dokumentów, a także wspomnień, wizji etc. koresponduje fragmentaryczna kompozycja powieści.

Legendy... to napisana po rosyjsku powieść o izraelskiej rzeczywistości i żydowskiej kulturze. Prozy pisarza nie nazwiemy ani emigrancką, ani neodiasporyczną; jest to proza humanisty poszukującego prawdy o człowieku, proza erudycyjna, będąca rodzajem gry intelektu, którą charakteryzują filozoficzna, alegoryczna głębia, wieloznaczność, a jednocześnie encyklopedyczna wierność historyczna. I właśnie jako taka powieść Soboleva stanowi odzwierciedlenie zachodzących obecnie w literaturze rosyjsko-izrealskiej procesów.

\section{BIBLIOGRAFIA}

Amusin A., Гора и город сквозь призму мифа, Portal Intelros. Intellektualnaya Rossia, http://www.intelros.ru/readroom/druzhba-narodov/d4-2017/32797-gora-i-gorod-skvoz-prizmu-mifa.html (dostęp: 1.10.2018).

Brandstaetter R., Czytanie Pisma Świętego jako modlitwa, Warszawa 1986.

Fijalkova L., Между Хайфой, Хефой, Нефасой и Хефбургом: творимая легенда Дениса Соболева, „Новое литературное обозрение” 2017, nr 147(5), http:// www.nlobooks.ru/node/9033 (dostęp: 1.12.2018).

Frank D.H., Leaman O., Historia filozofii żydowskiej, tłum. P. Sajdek, Kraków 2009.

Katsman R., Demarginalization of Contemporary Russophone Literature in Israel, http://www.academia.edu/35544512/Demarginalization_of_Contemporary_Russophone_Literature_in_Israel (dostęp: 12.11.2018).

Katsman R., Wstęp, przeł. A. Mrózek [w:] Z Rosji do Izraela. Opowiadania, Katowice 2018.

Katsman R., Иерусалим: диссипативный роман Дениса Соболева, http://magazines.russ.ru/nlo/2017/1/ierusalim-dissipativnyj-roman-denisa-soboleva.html (dostęp: 10.12.2018). 
Katsman R., Учиться ходить, „Нева” 2017, nr 5, http://magazines.russ.ru/media/ uploads/2017/06/21/13_КАЦМАН.pdf (dostęp: 1.10.2018).

Krajewski S., Żydowskie studiowanie Tory, ,Verbum Vitae” 2005, nr 7, http://dlibra. kul.pl/Content/21416/04_Krajewski.pdf (dostęp: 1.10.2018).

Michalska-Suchanek M., Dennis Sobolev [w:] Z Rosji do Izraela. Opowiadania, Katowice 2018.

Oz A., Oz-Salzberger F., Żydzi i słowa, tłum. P. Paziński, Warszawa 2014.

Pороша А., Легенды горы Кармель, http:/www.sunround.com/club/journals/ 35popova.htm (dostęp: 10.10.2018).

Rojtberg N., „Иерусалимский журнал” 2017, nr 56, http://magazines.russ.ru/ ier/2017/56/o-novyh-knigah-vilyama-batkina-i-denisa-soboleva-pr.html (dostęp: 10.11.2018).

Sobolev D., Легенды горы Кармель: Четырнадиать историй о любви и времени, Sankt Petersburg 2016.

Waszkielewicz H., Powietrzna trylogia Diny Rubiny [w:] Rosja w krysztale. Rozważania, fakty i miraże, red. D. Oboleńska, U. Patocka-Sigłowy, K. Arciszewska, K. Rutecka, Gdańsk 2014.

Weiss Sz., Hagada, opowieść o tożsamości, https://wszystkoconajwazniejsze.pl/prof-szewach-weiss-hagada-opowiesc-o-tozsamosci/ (dostęp: 1.10.2018). 